\title{
THE LABOUR PARTY IN LEICESTER: A STUDY IN BRANCH DEVELOPMENT
}

The purpose of this article is to examine the development of a branch of the British Labour Party by contrasting its activities before and after 1918. In so doing, it is hoped to illustrate the nature and extent of the influence of the Independent Labour Party (the I.L.P.), with especial reference to the position of the I.L.P. within the local branch of the Labour Party.

The I.L.P. was formed at Bradford in 1893 , and from the start it adopted a distinctively Socialist aim. ${ }^{1}$ Although it failed to achieve the status of a mass party, its propagandists were instrumental in converting the trade unions to the cause of independent Labour representation. ${ }^{2}$ These efforts were realised with the formation of the Labour Representation Committee (the L.R.C.) in I900. The L.R.C. was a federal body which pledged itself to maintaining an independent Labour Group in Parliament, but which did not commit itself to specifically Socialist objectives. It relied for its local organisation primarily on the Trade Unions, Trades Councils, and the I.L.P. Of these organisations, only the I.L.P. was specifically political, and so, in those areas where its following was strong, the I.L.P. played a dominant role in the development of the local branch. Leicester was one such area.

However, in 1918 the Labour Party adopted a new constitution. ${ }^{3}$ This affected the relations between the Labour Party and the I.L.P. in two main ways. First, it gave to the Labour Party a Socialist objective

\footnotetext{
1 At the inaugural conference in Bradford in 1893, a motion that the party be called the "Socialist Labour Party" was defeated, but the conference declared the objective of the party to be "the collective ownership of the means of production, distribution, and exchange". H. M. Pelling, The Origins of the Labour Party, I880-1900, London I954, pp. I 24-I 25.

2 Pelling, op. cit., p. 233. "The whole strategy of the party from its foundation in 1893 was based on the conception of collaboration with the trade unionists with the ultimate object of tapping trade union funds for the attainment of Parliamentary power."

${ }^{3}$ See G. D. H. Cole, A History of the Labour Party from 1914, London 1948, pp. 44-81.
} 
very similar to that of the I.L.P., ${ }^{1}$ and thereby challenged the claim of the I.L.P. to be the "Socialist vanguard" of the movement. Secondly, it introduced individual membership sections for local Labour Parties. Hitherto the I.L.P. had been the only medium through which individuals could participate in the work of the Labour Party. The new individual membership sections threatened to challenge this unique function, and with it the value of the I.L.P. as the most active propagandist body at the local level.

With these changes in mind, it is intended, in considering the Leicester Labour Party, to emphasise the role of the I.L.P. as the vital element in the Party in "the heroic days of 1900 to I914." 2 Secondly, the changing activities of the Party after 1918 will be examined in the light of the relationship between the Labour Party and the I.L.P. It is hoped that in this way it may be possible to consider the extent to which changes in the Constitution of 1918 were responsible for the decline of the I.L.P.

$$
* * *
$$

In the second half of the nineteenth century Leicester was a stronghold of Liberalism and Nonconformity. Its industry developed principally around the hosiery and boot and shoe trades, and although the hosiery workers showed little signs of political consciousness, the boot and shoe operatives, in Leicester and elsewhere, tended to be "strongly Socialistic" 3 in their policies.

In Leicester, however, the very strength of the Liberal Party proved an obstacle to Socialist development, for a majority of the Trade Union leaders, including those of the National Union of Boot and Shoe Operatives, were long convinced that working-class interests were best represented by Liberalism. The indicator of such feelings, and of the slow conversion of the Unions to the idea of independent representation, was the Leicester Trades Council. This body was composed of delegates from the Trade Unions in the area: when it

1 The Labour Party Constitution of 1918 , Section 2, Clause 4, declared one object of the Party to be "To secure for the producers by hand or by brain the full fruits of their industry, and the most equitable distribution thereof that may be possible, upon the basis of the common ownership of the means of production and the best obtainable system of popular administration and control of each industry and service" (Cole, op. cit., p. 72). ${ }^{2}$ M. Duverger, Political Parties, London 1954, p. 27. Duverger suggests that, in the life of Socialist branches generally, their activities have diminished since their early years. This he attributes to an "evolution in the social structure of the branch as its purely working-class character diminishes." The present study, it should be noted, is concerned mainly with developments in the political structure of the branch in question.

3 The phrase is used by Keir Hardie in reviewing the political situation in Leicester in 1894. (Labour Leader, 1.9.1 894). The industrial reasons for the radicalism of the boot and shoe operatives are briefly reviewed by Pelling, op. cit., p. 209. 
was established in 1872 it had only eight affiliated Unions, but by 1892 it represented 43 trades, and 17,000 Unionists." As a "local Parliament of Labour", 2 the Council spent much of its time reviewing and condemning local industrial conditions, but it also took an interest in local politics, and by 1894 several of its members had already been elected, under Liberal auspices, to the Town Council. However, although the years of its significant growth (1872-I 892) represented in Leicester the development of organised Unions, and the spread of various Socialist societies, the Trades Council, with minor vacillations, continued to support the Liberal Party and to discourage independent Labour representation.

During this time the ground was prepared for the advent of the I.L.P. by the various Socialist and Labour Societies which were established, though often very precariously, in Leicester. By 1894 the less transient of these societies included an Anarchist Society, branches of the Social Democratic Federation, the Christian Socialists, and a Labour Club. ${ }^{3}$ It was from the Labour Club that the initiative came for the establishment of a branch of the I.L.P. Hitherto the Club had been social rather than political - so much so, indeed, that Keir Hardie had found it necessary to warn the members against turning it into a "lounge for loafers", adding, somewhat pessimistically, that "liquor and labour won't mix".4 However, it had been customary for the Club to provide facilities for Socialist speakers. When in 1894 the second seat of Leicester's two-member constituency fell vacant, the politically active of the Labour Club asked the I.L.P. to nominate a candidate. Joseph Burgess, the editor of the "Workman's Times", was nominated. The preparation was hurried, and Burgess came bottom of the poll, but he nevertheless secured over 4,000 votes, and the local Socialists were so encouraged that they proceeded to form a branch of the I.L.P. ${ }^{5}$

The branch thus formed gave no early indication of being more permanent or successful than any of the other Socialist societies. In

1 Trades Union Congress Souvenir, Leicester 1903.

2 For a brief account of the character, functions and weaknesses of the Trades Councils, see S. and B. Webb, The History of 'Trade Unionism (Revised Edition), London 1920, pp. 453-457, and 557-561.

3 The Labour Club was "an organisation for political action, social and intellectual intercourse, recreative and mental improvement, and the better development of Labour principles in general" (Leicester Trades Council Yearbook, 1894).

4 Labour Leader, 2.6.1894.

5 An account of this election, which was of some importance as an indication of the growing strength of the Labour movement, may be found in Christian Commonwealth, 20.4.19xo. 
the elections of 1895 and 1900 the I.L.P. vote remained at approximately 4,000 , but membership increased only very slightly and the local Socialists were hard pressed to keep the Party in existence. Some of the reasons for its continued existence during these lean years are given below, but for the present it is sufficient to note that the early failure to secure electoral success, and to reach the dimensions of a mass party led the I.L.P. to seek the support of the Trade Unions. In Leicester this was achieved through the medium of the Trades Council.

For all its weaknesses, the Trades Council was the only organisation that brought the Trade Unions together at the local level. The "conversion" of its delegates, therefore, became the objective of the I.L.P. in the $1890^{\circ}$ 's. By 1900 the Council seemed fully in support of the I.L.P., for in that year it supported Ramsay MacDonald, the I.L.P. candidate, to the exclusion of the Liberals, and it became one of the first Trades Councils to affiliate to the Labour Party. ${ }^{1}$ It thus became an important link between the I.L.P. and the Trade Unions, and it was largely through the medium of the Council and the promptings of MacDonald, that in 1902 the Leicester Labour Representation Committee (the L.R.C.) was established. ${ }^{2}$

The L.R.C. was federal and indirect since it had no individual membership of its own. It consisted of delegates from the Trade Unions, co-operative societies and the I.L.P.; all these societies paid an annual affiliation fee and the Trade Unions paid an additional fee of one penny per member per annum. The committee was also empowered to make a special appeal to its member societies for funds for Parliamentary elections. Candidates for elections were proposed by affiliated societies, who were then made responsible for contributing at least two-thirds of the election expenses. The Committee as a whole simply endorsed the candidature, and reserved the right, when no others were forthcoming, to nominate its own candidates.

The L.R.C. thus fulfilled a limited and specific function. It harnessed the organization and the finances of the Trade Unions to the task of nominating independent labour candidates. At the same time it made no declaration of policy other than that of maintaining an independent party, enlisted no individual section, and made no attempt to create a

1 Pelling, op. cit., p. 244. Appendix B.

2 The Infancy of the Labour Party (pamphlet collection), Vol. I, ff 83-86. MacDonald's influence was considerable, and he appears to have been largely responsible for the constitution of the Leicester L.R.C. This constitution was subsequently quoted by MacDonald and Arthur Henderson as a model for local organisations. (See F. Bealey and H. M. Pelling, Labour and Politics, 1900-1906, London 1958, p. 237 et seq.) 
social life or to organise systematic propaganda. The Executive Committee of eighteen met once every month, and the General Committee once every year.

Thus the driving force behind the local movement continued to be the I.L.P., which dominated the offices of the L.R.C. up to I9I4, despite the fact that its formal delegation to the Executive Committee numbered only three out of eighteen. During this time, the L.R.C., following the national lead, had changed its name to the Labour Party, but the organisation and relations with the I.L.P. remained substantially the same. After the formation of the L.R.C. the distinctive function of the I.L.P. lay in the field of propaganda, and it was so successful in this respect that by rgro only Bradford had a larger membership. "The main object of the I.L.P.'s existence", said the "Leicester Pioneer", "is to propagate Socialism among all classes of the community." 1

It has been pointed out that the constitutional position changed considerably in 1918, when the Labour Party adopted a Socialist objective, and introduced individual membership. Moreover, with these changes the Labour Party endeavoured to subordinate local parties to the centre, and to regulate them more closely than had previously been the case. ${ }^{2}$ With these changes in mind this study seeks to point out some of the differences between the pre-war and post-war character of the Local Party. For purposes of analysis it is convenient to describe the pre-war period with reference to propaganda, the influence of the churches, and local government.

PROPAGANDA

The activities of the early I.L.P. are marked by the vigour of its campaigning, and the enthusiasm of its members. In the years between I 895 and 1900 popular opinion was generally antipathetic to Socialism, but largely by sheer enthusiasm and determination the local Socialists continued not only to keep the I.L.P. in being, but to make very slight advances. ${ }^{3}$ Party activity took the form mainly of public meetings which were held in the open-air of the market-place every summer - in competition with all manner of other speakers - and, when it could be afforded, indoors during the winter. Two such meetings were held every Sunday, and in good weather attendances

${ }^{1}$ Leicester Pioneer, 23.2.1907.

2 Cole, op. cit., p. 45 .

${ }^{3}$ For an account of the early activities of the Party propagandists, see Phillip, Viscount Snowden, An Autobiography, London 1934, Vol. I, pp. 70-84. 
were often estimated, though doubtless optimistically, at several thousands.

Such meetings were high-lighted by the visits of guest speakers such as Keir Hardie, the Glasiers, MacDonald and Snowden, but the burden of this arduous work - augmented not infrequently by the eleventh-hour failure of the visiting speaker - fell upon the local Socialists. These men were often Nonconformist preachers, Salvation Army leaders, or Sunday-School teachers, and their previous experience in public speaking was of great value to the I.L.P. From time to time this weekly routine was reinforced by the "Mission Weeks" which were organised by the National Administrative Council of the I.L.P. The Mission Weeks were in fact recruiting drives during which meetings were held every day of the week, and often three or four were held on the same evening in different parts of the town.

The meetings were the backbone of Party activity, and the main reason for its existence. On the one hand they made recruits, who might work for the Party and contribute to its funds. On the other hand, they raised money directly, for collections taken at meetings constituted by far the largest item in the Party revenue, and at good meetings large quantities of Party literature were sold, with some profit to the Party. In I897, for example, the income from the Sunday meetings was $£ 187$, as compared with a mere $£ 36$ from membership fees. ${ }^{1}$ Inevitably, finance was the greatest difficulty, and the net effect of all its activity was that the Party barely kept itself in existence. The Annual Report of 1899 , lamenting the missing contributions of the 4000 electors who voted for I.L.P. candidates, commented: "At the present our income barely suffices to cover the necessary expenses of organization, leaving all election expenses to be raised by special collections." 2 In such a position the prospect of tapping trade union funds must have been a most attractive one to the local Socialists.

In 190 , following the creation of the L.R.C., a weekly newspaper, the "Leicester Pioneer", was acquired, which thenceforth became the official organ of the Local Party. The acquisition of the "Pioneer" was largely due to the initiative of Ramsay MacDonald, who was now firmly established as the I.I.P. candidate for Leicester, and who subsequently contributed greatly to the "Pioneer" in both writing and financial assistance. ${ }^{3}$

1 Labour Leader, 22.1.1 898.

2 I.L.P. News, February 1900.

"It is unlikely that the "Pioneer" paid for itself financially. In a letter to Glasier in I910, MacDonald, writing of his financial position commented: "I have invested nothing, and 
The "Pioneer" was devoted primarily to local Party news, and only secondarily to national developments. It reported meetings, gave biographical sketches of local leaders, discussed municipal affairs, and paid considerable attention to the more social aspects of I.L.P. activity. Reports of social evenings, holidays into the country for the children, the progress of the "I.L.P. Scouts", and the affairs of the flourishing Clarion Cycling Club provide a useful insight into the life of the Party, and the reasons for its success. In short, it was as much a club as a political party. The wives of the members supported the social evenings, the children went on outings, and the I.L.P. Sunday Morning Classes provided for those who sought education. Its popularity was thus founded at least partially on the extent to which it provided facilities for social as well as political activity; and this in turn would suggest that its appeal was directed mainly to workingclass families who sought social outlets, but who could not afford other forms of recreation. The success of the I.L.P. in Leicester as compared, for example with the failure of the Social Democratic Federation, and the fact that in its early years the membership was almost entirely working-class, may well be accounted for in this way.

This suggestion is supported to some extent by a consideration of the influence of the various churches on the Party. The impact of the churches merits separate consideration, but for the present we may note that religious influences in the Party would further strengthen its appeal to devout, church-going members of the working class.

\section{THE INFLUENCE OF THE CHURCHES}

Throughout the nineteenth century the Liberal Party in Leicester was closely allied with the strong Nonconformist chapels of the area. The early Labour Party also possessed ties with the churches, but the exclusive alliance with Nonconformity is not to be found. On the one hand, the continued alliance of the Nonconformist ministers with the Liberal Party ${ }^{1}$ encouraged the I.L.P. to establish direct links with the more socially-minded clerygmen of the Anglican Church. But, paradoxically, the leading members of the I.L.P. continued to be drawn from the ranks of Nonconformity. We may examine these religious influences in the origins of the I.L.P. leaders, in the practices

I am committed to some things which are likely to cost me dear - amongst others my dear old "Pioneer". Quoted in Lord Elton, The Life of James Ramsay MacDonald, London 1939, p. 189.

1 The Nonconformist ministers were often dependent financially on the richer members of their congregation, and this may account for their relative conservatism in social matters. See Pelling, op. cit., p. 136. 
followed at Party meetings, and in the several religious organisations which were closely associated with the Party.

It is clear from biographical details of the pioneers of the I.L.P. in Leicester that its leaders were largely drawn from the various Nonconformist churches of the borough. Many of them, moreover, had taken an active part in church affairs, commonly serving as laypreachers and Sunday-school teachers, or as leaders of the Salvation Army. When they joined the I.L.P., they were often dissatisfied with the policies of both the Liberal Party and their chapels, but they tended to retain their religious zeal and practices. This may be illustrated by quoting a typical account of the activities of a Wesleyan in the I.L.P.:

"The I.L.P. soon took the devotion which he had given to the Chapel, and which was of an unusual character, as he thought nothing of attending five services on Sunday besides several in the week. It is not surprising, therefore, that he soon became known as one of the hardest workers in the Labour movement. The South Leicester Labour Church, one of the most successful Sunday afternoon meetings in the town, is one of the results of his energy." 1

The practice of singing hymns at political meetings was commonplace, and as late as 1916 the Leicester I.L.P. issued a song book of Labour songs set to the tunes of popular hymns. The Annual Harvest Festival also became an I.L.P. tradition, consisting in part of a religious service, and in part of a social gathering, when efforts were made to secure additional funds for the Party. Hence the "Pioneer" pointed out that the Party "was the better both morally and financially for it having been held; morally because the address and fraternising together have proved inspiring, and financially because the proceeds have not been small." 2 The Harvest Festivals were a prominent feature of the I.L.P. programme, although the practice does not seem to have been common amongst other I.L.P. branches, and they remained so until the I920's, when they disappeared along with many other features and activities of the Party.

By far the most important of these religious practices, however, were the Labour Churches which sprang up in Leicester after the turn of the century. Established in 1905, the Churches came to flourish in Leicester some time after they had declined in importance elsewhere. The purpose, said one of the Church Secretaries, was not to teach any

1 Trades Union Congress Souvenir, Leicester r903.

2 Leicester Pioneer, 21.9.1907. 
religious creed, but "to supplement the work of the ordinary churches by getting men and women to study the social problems of our times, and by rousing them to a sense of their duties and responsibilities as citizens." 1 Since the churches met each Sunday throughout the winter months, they fitted admirably into the I.L.P. propaganda programme, and the active encouragement given to them by the I.L.P. was doubtless based on the supposition that they might well attract people who would be reluctant to listen to I.L.P. propagandists elsewhere. The Churches were unorthodox in the extreme; the congregation was working class; the service consisted partly of hymns and prayers, but also of "sermons" on contemporary social problems such as Capitalism, Democracy, Character and The Problem of the Unemployed; and the preachers represented all shades of religious belief, ranging from the vicar of the largest Anglican Church in the town to the president of the Leicester Secular Society. The history of the Labour Churches is short, and by 1910 they had virtually disappeared from the local scene. Their significance, however, remains. On the one hand they emphasise the rebellion of the I.L.P. leaders against the political affiliations of their respective chapels. On the other they are testimony to the powerful religious drive which was such a marked characteristic of the early years of the Party.

Two further organisations may be noted as indicative of the increasing interest of the Anglican clergy in the I.L.P. movement. First, a branch of the Christian Social Union (the C.S.U.) was formed in Leicester before 1900, and in the following years it was largely controlled by certain Anglican clergymen who actively associated themselves with the I.L.P. Secondly, in 1907 an organisation of Anglican clergymen, the Church Socialist League (the C.S.L.), was established with the avowed aim of forming "a definitely Socialist Society, by means of which the isolation of Socialists in the Church could be destroyed". ${ }^{2}$ The C.S.L. rapidly superseded the C.S.U. in terms of activity, but neither seems to have survived for long, and there is no evidence of their functioning after the war.

Part of this decline of religious practices in the I.L.P. may doubtless be explained in terms of the relative decrease in church-going during the twentieth century. But for the present purpose it is sufficient to note that the impact of religion on the Local Party occurred almost entirely in the early years of its development. It may be suggested

${ }^{1}$ Ibid., 27.10.1906.

2 Leicester Pioneer, 9.2.1907. Previously the Pioneer had commented: "There is no more remarkable sign of the times than that presented by the awakening of a large section of the Anglican clergy to a consciousness that their work lies largely in the direction of making earth more like heaven..." (Pioneer, 24.2.1906). 
that during these years religious practices broadened the basis of the appeal of the I.L.P. to working-class people who were accustomed to seeking consolation and diversion in church-going. It was not only the Labour Party which outgrew these religious practices, but also (when it reached the dimensions of a mass party), the I.L.P. itself; for by this time it had developed a formal organisation which made impossible the close, face-to-face contacts amongst members on which social and religious activities had previously thrived.

After a consideration of Party activity in local government, then, the remainder of this study will be devoted to the changes which accompanied the growth of the I.L.P., and the contrast between this and the development of the Labour Party after i918.

\section{LOCAL GOVERNMENT}

The Local Party has been described as one which was primarily concerned with local conditions, and it was therefore natural that much interest should centre on local government. Labour policy in local government may be seen as two-fold: first, it sought to influence social conditions by active participation on municipal committees, and by piece-meal reform whenever this was possible; and secondly, it tentatively evolved - but never realised - a recognizably Socialist policy based on the municipality.

As a small minority group on the Town Council and the Board of Guardians the Labour Party could do little to influence policy, but as individuals serving on committees there was much to be gained in terms of experience and reform. Hence the Board of Guardians was an important target for I.L.P. permeation, and from this committee they were able, for example, to insist on humanising the administration of the Poor Law, and on the improvement of conditions in the Workhouse. On the Town Council, they pressed for cheaper allotments, improved sanitation, better artisan dwellings, higher rates of pay and conditions of work for municipal employees, and they made steady progress in all these fields. A typical report of their early activities commented thus: "Owing to the action of the I.L.P. members, the Leicester Town Council has held, for two years, the premier position by paying the street sweepers and labourers a halfpenny more than any town within sixty miles, and at the last Council meeting the I.L.P.-ers successfully carried a resolution which gave another half-penny per hour to 205 labourers..." 1

There was not at this time a distinctively Socialist policy in local government, but in the years after 1910 such a policy slowly emerged. ${ }^{1}$ I.L.P. News, February 1899. 
It amounted in essence, to the municipalization of services and productive industries. As proof of the value of such measures, the Labour Party could point to the previously successful municipalization of gas, electricity, and, in 1900, of the tramways. They now sought to expand the functions of the municipality even further, and the "Pioneer" proclaimed that "the greater the control the municipality exercises in the chief productive industries, the stronger the safeguards against irregularities in trade, and the more facilities we shall have as a community for providing useful and remunerative employment all the time". 1 The 19r4-1918 War temporarily suspended such thinking, but in I9I9 the need for an electoral programme was met by a manifesto which advocated a thorough-going policy of municipalization. Proposals were put forward for municipal trading in coal, milk, and bread; for the organisation of savings banks and public houses under the Corporation; and for the acquisition of land and the development of housing estates.

In fact, the Corporation never assumed this role, and when, in 1928 , the Labour Party finally obtained a majority on the Town Council, the reformist zeal had evaporated, for no mention is to be found of such sweeping reforms. With the abolition of the Board of Guardians in 1929, the scope for reformist activities in the local sphere diminished still further.

THE I.L.P. AND THE LABOUR PARTY

The foregoing description of the I.L.P. has been concentrated on the years 1894 to 1914 in the belief that during this period the Party fulfilled social and religious as well as political needs. For the greater part of this period membership had grown steadily, but not spectacularly. The initial paying membership of 54 in 1894 had grown to 225 in 1898,2 due almost entirely to the hard work and dedication of its original members. Between I900 and 1912 the I.L.P. gained steadily in membership, and, to judge from the occasional figures published, one may guess at a membership of perhaps 800 in 1912 . This was the period of maximum activity, when the Party was strong enough to be effective, but small enough to maintain its face-to-face community among members.

After I9I 2, however, when the I.L.P. was the second largest branch in the country, membership grew apace; by 1916 it stood at 1.216 , and by 1918 at $2.300 . .^{3}$ Despite the competition of the individual section

1 Leicester Pioneer, 10.3.Ig08.

2 I.L.P. News, July 1898.

${ }^{3}$ Labour Leader, 14.3.1918. 
of the Labour Party, there was no significant decline in membership until after 1925. Meanwhile the remarkable increase in membership during and shortly after the war raised the I.L.P. to the status of a mass party, for $\mathrm{I} \%$ of the population of Leicester were now Party members, and the same percentage over the whole country would have given a membership of 500,000.

This great increase may be largely attributed to the policy of the I.L.P. in general towards the war, and of MacDonald in particular. The pacifism, or alleged pacifism, of MacDonald was extremely unpopular with the majority, but it prompted many others to join the Party. It is worth noting, however, that the motives of those who joined the Party were now very diverse, and there was no longer that homogeneity of origin and background which had existed in the earlier days. ${ }^{1}$

Moreover, a membership so large now involved problems of organisation, and it is during this period that the question of maintaining interest and activity amongst members is first discussed. The "Pioneer" was supplemented in I914 by the publication of a news sheet, "Monthly Notes", which was designed to meet "the need for a regular and systematic means of keeping members in touch with, and stimulating interest in, the work of the Party." 2 In the same year, the I.L.P. took the advice of the National Administrative Council, who suggested that "attention should be given to a forward movement in organisation... the obligations, responsibilities and membership of the Leicester I.L.P. have grown to such an extent that voluntary work has reached the limit, and cannot cover the work effectively." 3 As a result of this report a full-time organising secretary was later appointed to serve both the I.L.P. and the Labour Party.

But as membership and organisation increased, the activities of the I.L.P. diminished. The decline of religious practices has already been noted. Perhaps as a corollary to this, after the war the weekly round of meetings lost much of their appeal, and lack of funds, speakers and audiences brought many of the indoor meetings to an end. And finally, the "Pioneer", having become a much-reduced monthly broadsheet in 1924, ceased publication altogether in 1928. Meanwhile, the "Monthly Notes", despite its self-professed need, had ceased publication in 1919 .

${ }^{1}$ See, for example, E. Wertheimer, Portrait of the Labour Party, London 1930. He writes (p. I4): "In the years following immediately upon the War the I.L.P. became a refuge for all those radical, bourgeois malcontents whose war experience and disillusion had brought them into contact with the Socialist movement..."

2 Monthly Notes, December I $9 \times 4$.

3 Monthly Notes, February 1915. 
One may assume from this that the nature and functions of I.L.P. membership began to change in the post-war years. The popularity of the Party remained high, but an increasingly large part of the membership was purely passive, and the I.L.P. no longer seemed to be catering for needs other than the purely political.

The method of recruitment used by the Labour Party is even more indicative of this change in the nature of membership. Whereas the I.L.P. had secured its recruits mainly by propaganda meetings, the Labour Party was unable to do so, and it found the greatest difficulty in maintaining an active individual section. ${ }^{1}$ Throughout the 1920's the numbers remained small, and finally, at the beginning of 1929 , the Executive resorted to the appointment of a full-time, professional canvasser. ${ }^{2}$ Thereafter the membership increased rapidly, and by 1930 it was 1700,3 but the necessity of improving and revitalising the individual membership remained a recurring theme of subsequent annual reports.

As a parallel development to these changes, the activity of the Labour Party became markedly seasonal, and largely centred upon the promotion of a few large meetings each year, such as the May Day celebrations, at which large attendances and leading Party speakers were assured. At such times, moreover, the onus of organisation rested not so much on the voluntary workers as on the efforts of the full-time agent, who tended increasingly to become the centre of party activity. Since these changes occurred during a time when the total Labour vote in the borough was increasing rapidly, ${ }^{4}$ there was a marked trend in both the I.L.P. and the Labour Party, towards the contemporary idea of the local party as an organisation whose only significance lies in the maintenance of an efficient electoral machine.

$$
* * *
$$

It has been the purpose of this study to consider the Leicester I.L.P. against the background of the total organisation of the Local Party. The structure of the Labour Party is usually regarded as being indirect before 1918 , and "mixed" after 1918 in that it included both

\footnotetext{
1 As in other branches, the Labour Party owed much during this time to the Woman's Labour League, an affiliated and enthusiastic body which was of some importance during these years.

2 Leicester Labour Party Annual Report, 1930.

3 Leicester Labour Party Annual Report, 1931.

${ }^{4}$ From 13,044 in 1918 to 61,366 in 1929 .
} 
individual members and affiliated groups. ${ }^{1}$ If we consider the Local Party in these terms, however, the distinction is hardly valid. An indirect structure implies the lack of a distinctive party community, since the party is nothing but a confederation of its component groups. On the contrary, in the years 1900-r9i4 the Local Party created a community which was remarkable for its self-sufficiency.

The explanation of this lies in the role of the I.L.P. It has been pointed out that the I.L.P. dominated the L.R.C., and subsequently the Labour Party, up to I9I4, so that the trade unionists who formed the Labour Party were almost inevitably leading members of the I.L.P. Hence the structure of the Local Party, although nominally indirect, may be seen in reality as a flourishing I.L.P. which was able at election time to merge itself into the Labour Party - a committee whose extra-I.L.P. function was to bring the power of the trade unions to help the promotion of Labour candidates. In all matters other than purely electoral ones, the I.L.P. was the source of all local Party activity. As such it possessed a character and variety of purpose that distinguish it from the later concept of the branch as an organisation designed solely for electoral purposes.

Secondly, it is commonly held that after i 9 r 8 the I.L.P. surrendered its functions to the individual section of the Labour Party. It has been pointed out, however, that I.L.P. recruitment did not suffer from the competition of the Labour Party, for the individual membership section of the latter made very little progress in Leicester throughout the 1920 's. Moreover, its members were largely passive, and attendant, perhaps, on the call of the professional canvasser, so that the Labour Party leaned as heavily as ever upon its affiliated societies. It was thus unable to take over and continue the activities of the pre-igr 8 I.L.P.

On the other hand, the I.L.P. itself exhibited some of the same symptoms. Despite its increasing size, its activities contracted, and its membership became increasingly inactive. In accounting for the decline of the I.L.P. the constitutional changes of the Labour Party in 1918 doubtless had a long-term influence when taken into consideration with other factors such as the leadership and its policy at the national level. ${ }^{1}$ But the I.L.P. also changed in character. In its early days the "latitude" 3 of its politics, the evangelical fervour of its leaders, and the social opportunities which it created, had all appealed

${ }^{1}$ For a discussion of direct and indirect structures, see Duverger, op. cit., p. $s$ et seq. Briefly, the distinction is between the direct party in which "members themselves form the party community without the help of other social groupings", and the indirect party which is made up of "the union of the component social groups".

${ }^{2}$ See Cole, op. cit., especially pp. 277-278; Snowden, op. cit., Vol. II, pp. 745-747.

${ }^{3}$ An expression used by Keir Hardie, who early' attributed the success of the I.L.P. to the "latitudinarianism" of its politics. (Labour Leader, 22.1.1 898). 
to the working class. After the war these appeals were blunted: the working class sought diversion in other ways, the composition of its membership changed, and participation became less keen. It may well be that this change in composition and attitudes in itself contributed to the downfall of the I.L.P. 